TUNJUK AJAR: JURNAL PENELITIAN ILMU PENDIDIKAN

Volume 4, Nomor 2, Agustus 2021

P-ISSN: 2615-062X

E-ISSN: 2622-3554

http://dx.doi.org/10.31258/ita.v4i2.151-162

\title{
HUBUNGAN ANTARA MINAT MENJADI GURU SEKOLAH DASAR DENGAN KESIAPAN MENGAJAR MAHASISWA CALON GURU SEKOLAH DASAR
}

\section{Ulyani Lizamil Haqqi ${ }^{1 *}$, Gustimal Witri ${ }^{1}$, Suroyo Suroyo ${ }^{1}$, Bedriati Ibrahim ${ }^{1}$, Neni Hermita ${ }^{1}$}

${ }^{1}$ Fakultas Keguruan dan IImu Pendidikan, Universitas Riau, Indonesia *ulyani.lizamil0867@student.unri.ac.id

\section{ABSTRACT}

This study aims to find out the relationship between the interest in becoming an elementary school teacher and the teaching readiness of PGSD FKIP UNRI students. This study uses a quantitative approach with a survey method. This research was conducted at PGSD FKIP UNRI which involved 118 active students of PGSD FKIP UNRI class of 2018. The data collection technique in this study used a questionnaire with a sampling technique, namely total sampling. Total sampling is a sampling technique in which all members of the population are sampled in order to obtain representative research results. The validity test of the questionnaire used the product moment correlation technique, while the reliability test used the Alpha Cronbach formula. As for the prerequisite analysis test, the normality test and linearity test were carried out. Then do the hypothesis testing with the product moment correlation test. The level of significance of the analysis results was set at 5\%. This data analysis technique was carried out with the help of the SPSS version 21 program. The results in this study can be concluded that there is a positive and significant relationship between interest in being an elementary school teacher and Teaching Readiness of PGSD FKIP UNRI students class of 2018 which is shown by the results of the correlation coefficient $r$ count $(0,506)>$ r table $(0,180)$.

Keywords: interest in being an elementary school teacher; teaching readiness; preservice elementary teachers

\section{PENDAHULUAN}

Era globalisasi ditandai dengan adanya persaingan kualitas atau mutu yang menuntut pendidikan untuk meningkatkan kompetensinya. Pendidikan di sekolah dasar adalah pintu pertama bagi peserta didik untuk masuk jenjang pendidikan selanjutnya dan sebagai langkah persiapan peserta didik untuk mendapatkan kemampuan dasar ataupun untuk melanjutkan ke jenjang yang lebih tinggi(Izzaty, Rita Eka, Yulia Ayriza, 2017). Tenaga pendidik di Sekolah Dasar sebagai main person dalam meningkatkan kualitas pendidikan perlu meningkatkan kompetensi 
keguruannya. Karena sejatinya tenaga pendidik di Sekolah Dasar tidak bisa dilakukan oleh sembarang orang, karena para pendidik harus orang yang berkompeten di bidangnya. Hal ini sesuai dengan pendapat Ahmadi (2017) bahwa "guru akan mampu melaksanakan tanggung jawabnya apabila dia memiliki kompetensi yang diperlukan."

Berdasarkan hasil survei SNMPTN menempatkan prodi PGSD masuk ke dalam sepuluh besar prodi yang paling diminati, tingginya peminat prodi PGSD tidak lepas dari kebutuhan guru Sekolah Dasar yang selalu dibutuhkan hampir di seluruh provinsi di Indonesia setiap kali tes CPNS dibuka. Jumlah kuota yang dibutuhkan pada tes CPNS 2018 saja mencapai 12.624 lowongan yang tersebar di seluruh Indonesia(Rahayuni, 2019). Mengetahui banyaknya jumlah peluang penerimaan tes CPNS untuk kategori guru Sekolah Dasar, tentunya hal ini menjadi daya tarik akan tingginya minat untuk menjadi bagian dari lulusan prodi PGSD.

Universitas Riau (UNRI) merupakan salah satu perguruan tinggi yang memiliki Fakultas Keguruan dan IImu Pendidikan (FKIP) yang juga menyediakan berbagai program studi pencetak calon-calon guru di Sekolah Dasar yang akan mendidik bibit-bibit unggul bangsa yakni program studi Pendidikan Guru Sekolah dasar (PGSD).Berbagai macam teori diajarkan kepada mahasiswa Pendidikan Guru Sekolah Dasar (PGSD) untuk mempersiapkan kematangan mahasiswa dalam mengajar ketika sudah berprofesi guru nantinya.Untuk melatih kesiapan mengajar mahasiswa diajak mengenal lingkungan sekolah secara real sekaligus mempraktekkan teori yang mereka pelajari sebelumnya melalui mata kuliah Pengenalan Lapangan Persekolahan (PLP).

Kesiapan menjadi guru adalah suatu kondisi mahasiswa calon guru dilihat dari kemampuannya yang membuatnya siap untuk melaksanakan tugas utama sebagai guru yang dapat dilihat melalui pemahaman kompetensi guru (Maipita, Indra, 2018). Kompetensi juga menjadi tolak ukur untuk melihat kualitas seorang guru dalam melaksanakan tugasnya sebagai seorang pengajar dan pendidik (Pitaloka,dkk., 2021; Collins, 1974; Hermita, dkk., 2020; Hermita, dkk., 2021; Isjoni, Hermita, 2017; Kamaruddin, K, 2018; Tanu, T.W \& Hermita, 2021; Putra, 2019). Berdasarkan Undang-Undang No. 14 Tahun 2005 tentang Guru dan 
Dosen ada empat kompetensi yang harus dimiliki guru yaitu kompetensi pedagogik, kompetensi sosial, kompetensi profesional, dan kompetensi kepribadian. Dari beberapa hal yang mempengaruhi kesiapan mahasiswa dalam mengajar, faktor yang berasal dari dalam diri (faktor intrinsik) merupakan faktor yang terpenting dalam mempersiapkan kesiapan mengajar mahasiswa calon guru Sekolah Dasar. Hal ini sesuai dengan pendapat Lunandi (Yusri, 2017) sumber terkaya untuk bahan belajar terdapat dalam diri sendiri. Mahasiswa calon guru dikatakan menguasai kesiapan mengajar dengan matang apabila ia memiliki minat dari dalam diri untuk mengemban profesi sebagai guru. Minat menjadi guru akan timbul apabila ada kesesuaian antara profesi guru dengan keadaan mahasiswa calon guru tersebut.Upaya untuk mencetak tenaga pendidik profesional sesuai dengan yang diharapkan tidaklah mudah. Mahasiswa Pendidikan Guru Sekolah Dasar masih banyak yang kurang memahami dan kurang mengetahui mengenai profesi guru.

Rendahnya kompetensi dan profesionalisme profesi guru akan berdampak pada ketidaksesuaian antara peningkatan mutu pendidikan secara nasional dengan apa yang diharapkan (Sennen, 2017). Berdasarkan data persentase guru layak mengajar (Kemendikbud, 2017) untuk tingkat Sekolah Dasar $86,18 \%$ guru di SDN layak mengajar dan $84,66 \%$ guru di SD Swasta layak mengajar. Hal ini menunjukkan kesiapan mengajar oleh tenaga pendidik khususnya yang berada di Sekolah Dasar perlu ditingkatkan lagi. Berdasarkan latar belakang tersebut maka penelitian ini bertujuan untuk mengetahui hubungan antara minat menjadi guru Sekolah Dasar dengan kesiapan mengajar mahasiswa PGSD FKIP UNRI yang akan mengikuti PLP 2021.

\section{METODE PENELITIAN}

Penelitian ini merupakan penelitian kuantitatif dengan metode korelasi yang bertujuan untuk megetahui hubungan dari dua variabel. Variabel pada penelitian ini adalah Minat Menjadi Guru Sekolah Dasar sebagai variabel bebas dan Kesiapan Mengajar sebagai variabel terikat. Sampel ditentukan dengan teknik total sampling, di mana seluruh anggota populasi dijadikan sampel. Sehingga sampel yang digunakan yaitu seluruh mahasiswa FKIP PGSD Universitas Riau 
TUNJUK AJAR: JURNAL PENELITIAN ILMU PENDIDIKAN

Volume 4, Nomor 2, Agustus 2021

P-ISSN: 2615-062X

E-ISSN: 2622-3554

http://dx.doi.org/10.31258/ita.v4i2.151-162

angkatan 2018 yang akan mengikuti PLP 2021 yang berjumlah 118 mahasiswa. Penelitian ini dilaksanakan di Kampus Bina Widya FKIP PGSD Universitas Riau.

Instrumen penelitian yang digunakan dalam penelitian ini berupa angket/kuesioner yang disusun berdasarkan indikator minat menjadi guru Sekolah Dasar dan kesiapan mengajar. Dari indikator minat menjadi guru Sekolah Dasar dapat dirumuskan 20 butir pernyataan, sedangkan indikator kesiapan mengajar 24 butir pernyataan. Sebelum instrumen digunakan untuk pengumpulan data penelitian, terlebih dahulu dilakukan uji validitas dan uji reliabilitas data baik secara manual maupun menggunakan SPSS versi 21 agar kuesioner yang digunakan dalam penelitian benar-benar menghasilkan data yang valid. Dari hasil analisis data tersebut dapat disimpulkan bahwa instrumen minat menjadi guru Sekolah Dasar yang berjumlah 20 pernyataan dikatakan valid, begitu juga dengan instrumen kesiapan mengajar yang berjumlah 24 pernyataan juga dikatakan valid.Teknik analisis data yang digunakan selanjutnya yaitu uji Normalitas Kolmogrov-Smirnov dan Uji Linearitas, kemudian dilanjutkan dengan Uji Hipotesis dengan uji Korelasi Product Moment. Keseluruhan analisis data menggunakan program SPSS versi 21 dan juga secara manual.

\section{HASIL PENELITIAN}

\section{Deskripsi Minat Menjadi Guru Sekolah Dasar}

Kuesioner minat menjadi guru Sekolah Dasar disusun berdasarkan 3 indikator yakni kognisi (mengenal), emosi (perasaan), dan konasi (kehendak). Berikut adalah contoh kuisioner data minat menjadi guru Sekolah Dasar.

Tabel 1. Kisi-kisi Instrumen minat menjadi guru Sekolah Dasar

\begin{tabular}{ll}
\hline \multicolumn{1}{c}{ Indikator } & \multicolumn{1}{c}{ Pernyataan } \\
\hline $\begin{array}{l}\text { Kognisi } \\
\text { (mengenal) }\end{array}$ & $\begin{array}{l}\text { Saya membaca artikel tentang Pendidikan Guru Sekolah Dasar } \\
\text { di berbagai media untuk menambah wawasan tentang profesi } \\
\text { guru }\end{array}$ \\
\hline $\begin{array}{l}\text { Emosi } \\
\text { (perasaan) }\end{array}$ & $\begin{array}{l}\text { Menjadi Guru Sekolah Dasar sangat menyenangkan karena } \\
\text { selalu dikelilingi banyak anak-anak dalam setiap aktivitasnya }\end{array}$ \\
\hline $\begin{array}{l}\text { Konasi } \\
\text { (kehendak) }\end{array}$ & $\begin{array}{l}\text { Saya ingin menjadi guru Sekolah Dasar karena profesi ini sangat } \\
\text { diperhatikan oleh pemerintah }\end{array}$
\end{tabular}


Skala yang digunakan dalam angket minat menjadi guru Sekolah Dasar yaitu skala likert dengan empat alternatif jawaban. Skor minimal yang mungkin diraih oleh responden yaitu 20 dan skor maksimal sebesar 80 . Hasil pengambilan data ini kemudian ditabulasikan dan dihitung jumlah skornya. Berdasarkan perhitungan data, diperoleh skor minimal sebesar 48 sedangkan skor maksimal sebesar 78. Adapun pengkategorian data minat menjadi guru Sekolah Dasar dapat dilihat pada tabel 2 .

Tabel 2. Kategorisasi Deskriptif Persentase Minat Menjadi Guru Sekolah Dasar

\begin{tabular}{lllll}
\hline No. & Interval & Frekuensi & Persentase (\%) & Kategori \\
\hline 1. & $\mathrm{X}<58$ & 8 & $6,78 \%$ & Rendah \\
\hline 2. & $58 \leq \mathrm{X}<68$ & 52 & $44,07 \%$ & Sedang \\
\hline 3. & $\mathrm{X} \geq 68$ & 58 & $49,15 \%$ & Tinggi \\
\hline & Total & $\mathbf{1 1 8}$ & $\mathbf{1 0 0 \%}$ & \\
\hline
\end{tabular}

Berdasarkan tabel 2. di atas dapat diketahui bahwa untuk variabel minat menjadi guru Sekolah Dasar tergolong dalam kategori tinggi karena 58 dari 118 mahasiswa mendapat skor lebih dari sama dengan 68 dengan persentase sebesar $49,15 \%$.

\section{Deskripsi Kesiapan Mengajar}

Kuesioner kesiapan mengajar disusun berdasarkan 4 indikator yakni aspek materi, modal kesiapan, keterampilan operasional dan pemahaman kompetensi guru. Berikut adalah contoh kuisioner data kesiapan mengajar.

Tabel 3. Kisi-kisi Instrumen Kesiapan Mengajar

\begin{tabular}{cl}
\hline Indikator & \multicolumn{1}{c}{ Pernyataan } \\
\hline Aspek materi & $\begin{array}{l}\text { Sebelum melaksanakan kegiatan belajar mengajar saya akan } \\
\text { menyusun metode dan model pembelajaran yang menarik agar } \\
\text { peserta didik dapat menangkap materi pelajaran dengan baik }\end{array}$
\end{tabular}


TUNJUK AJAR: JURNAL PENELITIAN ILMU PENDIDIKAN

Volume 4, Nomor 2, Agustus 2021

P-ISSN: 2615-062X

E-ISSN: 2622-3554

http://dx.doi.org/10.31258/ita.v4i2.151-162

Kesiapan Saya hanya memperhatikan peserta didik yang mau memperhatikan saya ketika menyampaikan materi pelajaran

Keterampilan Sebelum pelajaran dimulai saya akan membimbing siswa untuk Operasional berdo'a sebelum belajar dan menanyakan kabar peserta didik saya hari ini

Pemahaman Saya akan berperilaku sesuai norma, religius, dewasa, arif, Kompetensi wibawa karna saya merupakan panutan bagi peserta didik \& Guru masyarakat sekitar

Skala yang digunakan dalam angket kesiapan mengajar yaitu skala likert dengan empat alternatif jawaban. Skor minimal yang mungkin diraih oleh responden yaitu 24 dan skor maksimal sebesar 96 . Hasil pengambilan data ini kemudian ditabulasikan dan dihitung jumlah skornya. Berdasarkan perhitungan data, diperoleh skor minimal sebesar 54 sedangkan skor maksimal sebesar 93. Adapun pengkategorian data kesiapan mengajar dapat dilihat pada tabel 4.

Tabel 4. Kategori Kesiapan Mengajar

\begin{tabular}{ccccc}
\hline No. & Interval & Frekuensi & Persentase (\%) & Kategori \\
\hline 1. & $\mathrm{X}<67$ & 2 & $1,70 \%$ & Rendah \\
\hline 2. & $67 \leq \mathrm{X}<80$ & 38 & $32,20 \%$ & Sedang \\
\hline 3. & $\mathrm{X} \geq 80$ & 78 & $66,10 \%$ & Tinggi \\
\hline & Total & $\mathbf{1 1 8}$ & $\mathbf{1 0 0 \%}$ & \\
\hline
\end{tabular}

Berdasarkan tabel 4. di atas dapat diketahui bahwa untuk variabel kesiapan mengajar tergolong dalam kategori tinggi karena 78 dari 118 mahasiswa mendapat skor lebih dari sama dengan 80 dengan persentase sebesar $66,10 \%$.

\section{Uji Normalitas}


Uji normalitas digunakan untuk mengetahui apakah sampel dalam berdistribusi normal atau tidak melalui pengujian. Uji normalitas dalam penelitian ini dilakukan dengan bantuan SPSS versi 21 dan secara manual dengan teknik pengujian Kolmogorov-Smirnov. Kriteria penetapan data berdistribusi normal atau tidak dengan cara membandingkan nilai Sig (2-tailed) pada tabel kolmogrovsmirnov dengan taraf signifikansi 0,05 (5\%). Dengan demikian dasar pengambilan keputusan bahwa nilai probabilitas dari koefisien K-S > 0,05, maka data berdistribusi normal. Sebaliknya jika nilai probabilitas dari koefisien $\mathrm{K}-\mathrm{S}<0,05$, maka data berdistribusi tidak normal. Hasil pengujian normalitas data dapat dilihat pada tabel 5 .

Tabel 5. Hasil Uji Normalitas

\begin{tabular}{cccc}
\hline Korelasi & Nilai signifikansi & Taraf signifikan & Keterangan \\
\hline $\mathrm{X} \rightarrow \mathrm{Y}$ & 0,339 & 0.05 & Berdistribusi normal \\
\hline
\end{tabular}

Berdasarkan tabel 5 hasil uji normalitas menggunakan rumus KolmogorovSmirnov dengan program SPSS versi 21 diketahui nilai signifikansi 0,339 $>0,05$ maka dapat disimpulkan bahwa variabel Minat Menjadi Guru Sekolah Dasar dan Kesiapan Mengajar dikatakan berdistribusi normal.

\section{Uji Linearitas}

Uji Linearitas bertujuan untuk mengetahui bentuk hubungan antar variabel bebas $(X)$ dan variabel terikat $(Y)$ linear atau tidak. Kriteria pengujian linearitas yaitu apabila hasil output data nilai signifikan $>0,05$, maka hubungan antara variabel bebas $(\mathrm{X})$ dan variabel terikat $(\mathrm{Y})$ bersifat linear. Atau dengan cara membandingkan nilai $F$, jika nilai $F$ hitung $<F$ tabel maka terdapat hubungan yang linear secara signifikan antara variabel bebas dan variabel terikat. Uji linearitas dalam penelitian ini dilakukan secara manual dan juga dengan bantuan SPSS versi 21. Hasil uji linearitas pada variabel minat menjadi guru Sekolah Dasar dengan kesiapan mengajar dapat dilihat pada tabel 6 .

Tabel 6. Hasil Uji Linearitas 
TUNJUK AJAR: JURNAL PENELITIAN ILMU PENDIDIKAN

Volume 4, Nomor 2, Agustus 2021

P-ISSN: 2615-062X

E-ISSN: 2622-3554

http://dx.doi.org/10.31258/ita.v4i2.151-162

\begin{tabular}{llll}
\hline Korelasi & F $_{\text {hitung }}$ & Signifikansi & Keterangan \\
$X \rightarrow Y$ & 1,587 & 0,061 & Linear
\end{tabular}

Berdasarkan tabel 6 di atas dari uji linearitas diperoleh nilai signifikansi sebesar 0,061 dan nilai $F_{\text {hitung }}$ sebesar 1,587. Diketahui bahwa $F_{\text {tabel }}$ untuk penelitian 2 variabel dengan $\mathrm{N}=118$ sebesar 3,92. Karena hasil perhitungan signifikansi $>0,05$ dan $F_{\text {hitung }}<F_{\text {tabel }}$ maka dapat disimpulkan bahwa antara variabel minat menjadi guru Sekolah Dasar dengan kesipaan mengajar terdapat hubungan yang linear.

\section{Uji Hipotesis}

Pengujian hipotesis dalam penelitian ini menggunakan analisis korelasi Product Moment. Analisis korelasi Product Moment digunakan untuk menentukan hubungan antara dua gejala interval (Suharsimi Arikunto, 2013). Kriteria pengambilan keputusan Menurut Sugiyono (2017) yaitu bila $r_{\text {hitung }}<r_{\text {tabel }}$, maka Ho diterima, dan $\mathrm{Ha}$ ditolak, sebaliknya bila $r_{\text {hitung }}$ lebih besar dari $r_{\text {tabel }}$ maka $\mathrm{Ha}$ diterima. Hasil uji korelasi product moment dari kedua variabel dapat dilihat pada tabel 7.

Tabel 7. Hasil Uji Korelasi Product Moment

\begin{tabular}{|c|c|c|c|}
\hline & & $\begin{array}{l}\text { Minat Menjadi } \\
\text { Guru SD }\end{array}$ & $\begin{array}{l}\text { Kesiapan } \\
\text { Mengaiar }\end{array}$ \\
\hline Minat Menjadi & Pearson & 1 &, $506^{\star \star}$ \\
\hline \multirow[t]{3}{*}{ Guru SD } & Correlation & & \\
\hline & Sig. (2-tailed) & &, 000 \\
\hline & $\mathrm{N}$ & 118 & 118 \\
\hline Kesiapan & Pearson &, $506^{* *}$ & 1 \\
\hline \multirow[t]{3}{*}{ Mengajar } & Correlation & & \\
\hline & Sig. (2-tailed) & ,000 & \\
\hline & $\mathrm{N}$ & 118 & 118 \\
\hline
\end{tabular}

Berdasarkan tabel di atas, hasil analisis korelasi Product Moment menujukkan bahwa koefisian korelasi Product Moment variabel Minat Menjadi 
Guru Sekolah Dasar dengan Kesiapan mengajar sebesar 0,506. Diketahui bahwa koefisien $r$ tabel dengan taraf signifikansi 0,005 dengan $\mathrm{N}=118$ sebesar 0,180. Hasil menunjukkan bahwa $r_{\text {hitung }}$ lebih besar dari harga $r_{\text {tabel }}(0,506>0,180)$, sehingga Ha diterima dan Ho ditolak. Maka dapat disimpulkan bahwa terdapat hubungan yang positif dan signifikan antara Minat Menjadi Guru Sekolah Dasar dengan Kesiapan Mengajar mahasiswa PGSD FKIP Universitas Riau angkatan 2018.

Koefisien korelasi yang didapat sebesar 0,506, dikarenakan bernilai positif maka dapat dikatakan bahwa variabel Minat Menjadi Guru Sekolah Dasar memiliki hubungan yang positif dengan Kesiapan Mengajar yang artinya bahwa semakin besar minat menjadi Guru Sekolah Dasar, maka akan semakin baik pula tingkat Kesiapan Mengajar.

Tabel 8. Interpretasi Koefisien Korelasi Nilai r

\begin{tabular}{cc}
\hline Besarnya nilai $\mathbf{r}$ & Interpretasi \\
\hline $0,00-0,199$ & Sangat rendah (Tidak Berkorelasi) \\
\hline $0,20-0,399$ & Rendah \\
\hline $0,40-0,599$ & Sedang \\
\hline $0,60-0,799$ & Kuat \\
\hline $0,80-1,000$ & Sangat Kuat \\
\hline
\end{tabular}

Sumber: Sugiyono, 2017

Berdasarkan tabel pedoman interpretasi koefisien korelasi di atas koefisien korelasi sebesar 0,506 terletak pada interpretasi kategori 0,40-0,599 sehingga dapat disimpulkan bahwa korelasi antara Minat Menjadi Guru Sekolah Dasar (X) dengan Kesiapan Mengajar $(\mathrm{Y})$ mempunyai hubungan yang sedang.

\section{PEMBAHASAN}

Sebelum masuk ke perguruan tinggi, setiap calon mahasiswa menyiapkan program studi yang akan ia pilih sesuai dengan minat dan bakatnya. Mahasiswa yang memilih program studi kependidikan khususnya Pendidikan Guru Sekolah Dasar seharusnya memiliki minat dan bakat menjadi seorang tenaga pendidik di 
Sekolah Dasar. Karena disetiap minat dan bakat yang tersalurkan dengan baik akan menghasilkan sesuatu yang baik pula. Sama halnya dalam memilih jurusan dalam perkuliahan, perlu diketahui hal yang membuat tingginya minat mahasiswa memilih program studi Pendidikan Guru Sekolah Dasar karena hal ini akan berpengaruh terhadap kesiapan diri mahasiswa untuk megajar kelak saat menjadi seorang guru.

Kesiapan mengajar mahasiswa ditandai dengan adanya pemahaman mahasiswa calon guru terhadap keterampilan dan kompetensikompetensi yang harus dimiliki oleh seorang guru serta kemampuannya mempersiapkan kegiatan belajar mengajar yang efektif layaknya seorang guru. Karena pada dasarnya kesiapan seseorang tidak timbul dengan sendirinya melainkan harus dipersiapkan terlebih dahulu. Kesiapan mengajar dapat timbul dari berbagai faktor yang mempengaruhi, salah satunya minat. Minat merupakan ketertarikan seseorang pada sesuatu hal, dan hal tersebut akan mendorongnya untuk melakukan suatu tindakan/pekerjaan. Mahasiswa yang berminat untuk menjadi seorang guru akan berusaha untuk menjadi apa yang diinginkannya.

Untuk menentukan hubungan antara minat menjadi Guru Sekolah Dasar dengan kesiapan mengajar, peneliti perlu melakukan uji prasyarat analisis terlebih dahulu yakni dengan uji normalitas dan uji linearitas. Dari hasil uji normalitas yang diperoleh dapat disimpulkan bahwa residual telah memenuhi asumsi distribusi normal. Sedangkan untuk uji normalitas diperoleh kesimpulan bahwa terdapat hubungan yang linear antara minat menjadi Guru Sekolah Dasar dengan kesiapan mengajar.

Berdasarkan hasil uji korelasi yang telah dilakukan dapat disimpulkan bahwa hubungan minat menjadi guru Sekolah Dasar dengan kesiapan mengajar berada dalam kategori sedang. Minat menjadi Guru Sekolah Dasar memiliki hubungan yang positif dan signifikan dengan kesiapan mengajar. Hal ini berarti setiap kenaikan variabel $X$ diikuti kenaikan oleh variabel $Y$. Semakin tinggi minat menjadi Guru Sekolah Dasar maka semakin tinggi pula kesiapan mengajar. Hal ini diperkuat oleh penelitian yang dilakukan oleh Kristina Rohayati Ratu pada tahun 2018 yang menyatakan bahwa kesiapan seseorang untuk mengajar ditunjukkan dengan kesiapan sikap baik secara fisik dan mental untuk 
mempraktikkan hal tertentu sesuai dengan kebutuhan dan keahlian yang dimilikinya. Sementara itu penelitian yang dilakukan oleh Yunita Ayuni pada tahun 2013 menemukan bahwa terdapat hubungan positif dan signifikan antara minat profesi guru terhadap kesiapan mengajar mahasiswa.

\section{SIMPULAN}

Berdasarkan data hasil penelitian yang diperoleh maka dapat disimpulkan bahwa terdapat hubungan yang positif dan signifikan antara Minat Menjadi Guru Sekolah Dasar dengan Kesiapan Mengajar Mahasiswa Pendidikan Guru Sekolah Dasar FKIP Universitas Riau angkatan 2018 dengan hubungan korelasi pada kategori sedang.

Dari hasil penelitian yang telah didapat, peneliti memberikan saran hendaknya mahasiswa Pendidikan Guru Sekolah Dasar FKIP Universitas Riau lebih meningkatkan minat dan kesiapannya untuk menjadi guru Sekolah Dasar. Karena Indonesia masih sangat membutuhkan generasi-generasi unggul dan tangguh untuk mendidik calon penerus bangsa di tengah kehidupan yang penuh dengan pengaruh globalisasi.

\section{DAFTAR PUSTAKA}

Ahmadi, F. (2017). Guru SD di Era Digital (1st ed.). CV. Pilar Nusantara.

Collins, M. (1974). Kebebasan Belajar untuk tahun 80-an. Colombus: Charles E. Merrill.

Hermita, N., Alim, J. A., Mulyani, E. A., Putra, R. A., Alpusari, M., Fauza, N., Sari, I. K., Chairilsyah, D., Rayendra, R., \& Anggoro, S. (2020). Analizing Elementary School Teacher's Understanding (ESTU) in Scientific Communication skills (SCs). Journal of Physics: Conference Series, 1655(1). https://doi.org/10.1088/1742-6596/1655/1/012102

Hermita, N, Wijaya, T. T., Fauza, N., Mulyani, E. A., Alim, J. A., \& Putra, R. A. (2021). The Important of the Community of Practice (CoP) in Improving the Primary School Teachers' Performance in Riau Province. Dinamika Jurnal IImiah Pendidikan Dasar, 13(1), 26. https://doi.org/10.30595/dinamika.v13i1.8712

Isjoni I, Hermita N, Samsudin A. (2017). Why Should History Teachers Develop 
Their Pedagogical Competences? Advanced Science Letters, 23(11).

Izzaty, Rita Eka, Yulia Ayriza, F. A. S. (2017). Prediktor Prestasi Belajar Siswa Kelas 1 Sekolah Dasar. Jurnal Psikologi, 44(2), 153-164.

Kamaruddin K. (2018). How Supervision Program Encourage History Teachers to Promote Their Pedagogical Competence? Advanced Science Letters, 24(11).

Kemendikbud. (2017). Rangkuman Statistik Persekolahan. PDSPK Kemendikbud. Maipita, Indra, T. M. (2018). Pengaruh Minat Menjadi Guru dan Praktik Program Pengalaman Lapangan (PPL) Terhadap Kesiapan Menjadi Guru pada Mahasiswa Jurusan Ekonomi Universitas Negeri Medan T.A 2017/2018. Jurnal Ekonomi Pendidikan, 8(6), 34-43.

Pitaloka, W B, Hermita N, Alim J A, Fauza N, Dipuja D A, Wijaya T T. Analyzing Primary Teachers' Peesonality Competence in Universitas Riau. DIDAKTIKA: Jurnal Pendidikan Sekolah Dasar, Jilid 4 Terbitan 1, hal 29-36.

Putra, Z. H. (2019). Elementary teachers' knowledge on fraction multiplication: An anthropological theory of the didactic approach. Journal of Teaching and Learning in Elementary Education,2(1), 47-52. http://dx.doi.org/10.33578/jtlee.v2i1.6964

Rahayuni, I. gusti A. A. (2019). Menumbuhkan Mental Entrepreneur Pada Mahasiswa PGSD Dalam Menghadapi Era Revolusi Industri 4.0. Prosiding Seminar Nasional Dharma Acarya Ke-1 Tantangan Dan Peluang Dunia Pendidikan Di Era 4.0.

Sennen, E. (2017). Problematika Kompetensi dan Profesionalismr Guru. Prosiding Seminar Nasional HDPGSDI Wilayan IV, Pengembangan Kompetensi SUmber Daya Manusia Menuju Pendidikan Dasar Yang Berkualitas, 16-21. Sugiyono. (2017). Metode Penelitian Kuantitatif, Kualitatif dan R\&D (18th ed.). Alfabeta.

Wijaya, T T \& Hermita, N. (2021). What is TPMK? The Best Way to Become The Best Math Teacher. AE Publishing, 2021.

Yusri, Y. (2017). Strategi Pembelajaran Andragogi. Jurnal Ilmiah Keislaman., 12(1), 25-52. 